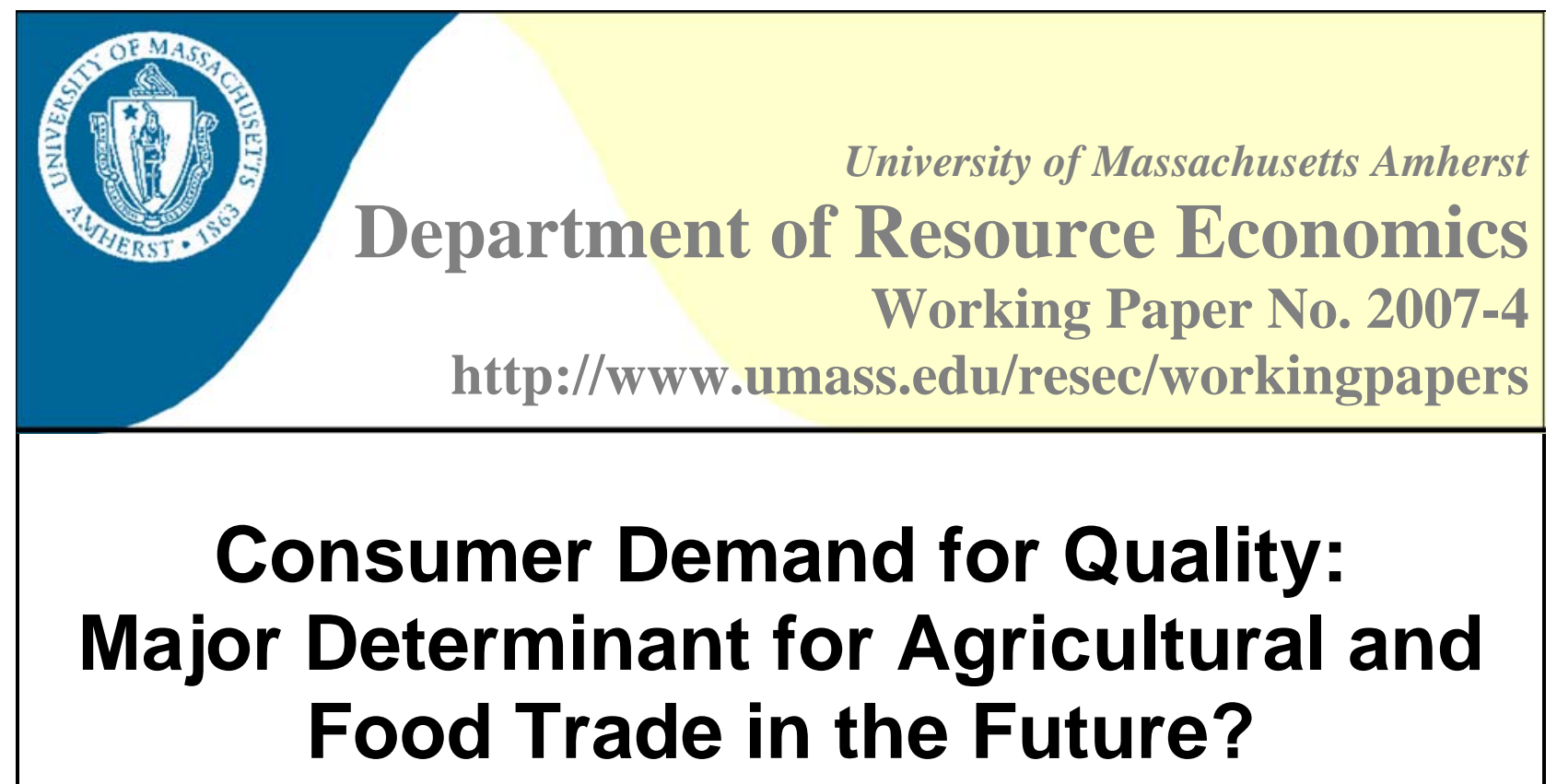

\author{
Julie A. Caswell ${ }^{1}$ and Siny Joseph $^{2}$
}

\begin{abstract}
:
The impact of consumer demand for quality on the agricultural and food system is an increased emphasis on quality differentiation but not all in the direction of upgrading quality. The more elite market segments are thriving and reaching growing numbers of consumers but the basic price/quality markets remain strong. Most recent economic studies find that consumers are willing to pay for food safety and other quality attributes, and for information about them. The magnitude of the valuations varies by food product, attribute, country, and study design. This literature and a case study of genetically modified foods suggest that consumer demand has a strong effect on agricultural and food trade.
\end{abstract}

Keywords: food quality, food safety, consumer demand, willingness to pay, international trade

JEL Classification: D12, L15, Q18

\footnotetext{
${ }^{1}$ Julie A. Caswell, Department of Resource Economics

University of Massachusetts, 215 Stockbridge Hall

80 Campus Center Way, Amherst, MA 01003

E: caswell@resecon.umass.edu P: 413-545-5735 F: 413-545-5853

${ }^{2}$ Siny Joseph, Department of Resource Economics

University of Massachusetts, 404 Stockbridge Hall

80 Campus Center Way, Amherst, MA 01003

E: siny@resecon.umass.edu P: 413-545-5710 F: 413-545-5853
} 


\title{
Consumer Demand for Quality: Major Determinant for Agricultural and Food Trade in the Future?
}

\author{
Julie A. Caswell \\ caswell@,resecon.umass.edu \\ and \\ Siny Joseph \\ siny@resecon.umass.edu \\ Department of Resource Economics \\ University of Massachusetts Amherst \\ 80 Campus Center Way \\ 215 Stockbridge Hall \\ Amherst, MA 01003 \\ Phone: (413) 545-5735 \\ Fax: (413) 545-5853
}

Julie A. Caswell is Professor and Siny Joseph is Research Assistant, Department of Resource Economics, University of Massachusetts Amherst. This research was supported by a United States Department of Agriculture: Cooperative State Research, Education, and Extension Service Special Grant to the Food Marketing Policy Center, University of Connecticut, and by a subcontract to the University of Massachusetts Amherst. 


\title{
Consumer Demand for Quality: \\ Major Determinant for Agricultural and Food Trade in the Future?
}

\begin{abstract}
The impact of consumer demand for quality on the agricultural and food system is an increased emphasis on quality differentiation but not all in the direction of upgrading quality. The more elite market segments are thriving and reaching growing numbers of consumers but the basic price/quality markets remain strong. Most recent economic studies find that consumers are willing to pay for food safety and other quality attributes, and for information about them. The magnitude of the valuations varies by food product, attribute, country, and study design. This literature and a case study of genetically modified foods suggest that consumer demand has a strong effect on agricultural and food trade.
\end{abstract}

Keywords: food quality, food safety, consumer demand, willingness to pay, international trade

JEL Classification: D12, L15, Q18 


\section{Consumer Demand for Quality: Major Determinant for Agricultural and Food Trade in the Future?}

Analyses of the effect of changes in consumer demand on agricultural and food trade have a tendency to begin with sweeping statements such as "consumer demand is a key driver of today's agricultural and food trade," "demand for quality is increasing among consumers around the world," or "the agricultural system is moving from being commodity based to being based in differentiated food products." While these statements may be generally true, they have the usual drawback associated with sweeping statements - they tend to obscure important facts. Here we focus on where consumer demand for specific food quality attributes, including safety, is coming from; its nature and level; and how likely it is to affect agricultural and food trade in the future.

\section{Trends in Consumer Demand}

Product quality is determined by the set of attributes or characteristics of a food product, as well as how those attributes and characteristics are assured and communicated to consumers. Information on food quality for consumers is featured in the media, and delivered by health care professionals, governments, consumer groups, and food processors and retailers as part of their advertising strategies. Overall, consumer food choices are influenced by a variety of factors including taste, convenience, price, available alternatives, health status, and cultural traditions. Consumers are thinking about quality attributes such as food safety, nutrition, organic production, fair trade, free range, animal friendly, and locally grown. There is nothing new in consumers caring about 
multiple attributes of food products but the continuing differentiation of food products means that consumers can get information on and care about a broader range of attributes.

Consumers come to the market with prior experience, a level of education, perceived quality risks, a quality consciousness, goals they hope to achieve in using the product, and other personal and situational factors. Companies use these factors to design marketing efforts and choose quality control systems that will produce quality and also allow them to signal (communicate) quality to consumers using indicators and cues, such as certification systems, labeling, and branding. These cues and indicators are particularly important for credence attributes that the consumer cannot evaluate even after consumption, such as whether there are pesticide residues in a particular tomato. The central point is that quality is multidimensional, as is quality signaling.

The impact of consumer demand for quality, including safety, on food markets must be considered in terms of market segments and industry developments. Some segments have strong demand for what they perceive to be higher quality products. For example, the organic market has been growing very rapidly in many countries. In the United States, the growth rate for organic products exceeded $20 \%$ in the years throughout the 1990s and is estimated to be 9-16\% through 2010 (Dimitri and Oberholtzer 2005). However, low price, or more accurately high value (price for quality), drives a large share of the food market. For example, fueled by high levels of efficiency in its supply chain and low prices, Wal-Mart has grown to be the largest food retailer worldwide. Most interestingly, the same consumer can dip into very different product and store markets to meet different needs. For example, recent research shows a marked increase in multi- 
outlet shopping. In addition, food markets in many less developed countries are rapidly adopting the supermarket format for food shopping (see, e.g., Reardon, Timmer, and Berdegue 2004).

Overall, the impact of consumer demand for quality on the agricultural and food system is an increased emphasis on quality differentiation but, and this is key, not all in the direction of upgrading product quality. Though the more elite market segments are thriving and reaching growing numbers of consumers, the basic price/quality markets remain strong, especially where lower income consumers face increasing budget challenges.

\section{Evidence on Consumer Willingness to Pay for Quality Attributes}

The role of consumer demand in shaping markets for agricultural and food products has been increasingly emphasized over the last two decades (McCluskey et al. 2005; Peterson and Chen 2005; Grannis and Thilmany 2002; Unterschultz, Quagrainie, and Veeman 1998; Magnusson and Cranfield 2005; Hobbs et al. 2005). A problem, however, is to identify causality —are changes in consumer demand shaping international agricultural and food markets, or are companies, other interest groups, and governments shaping consumer demand? Of course, the answer is both. Without attempting to capture causality, we review research done by several economists in recent years on consumer demand for a variety of quality attributes. The literature has become quite voluminous; our goal is to draw the implications of this literature for agricultural and food trade. 
Willingness to Pay for Food Quality: Overall Observations

We begin by making several overall observations based on our reading of the body of research on willingness to pay for quality attributes detailed in Table 1 and meta- or comparative analyses appearing recently in the literature (Lusk et al. 2005; Florax, Travisi, and Nijkamp 2005; Ehmke 2006; McCluskey, Grimsrud, and Wahl 2007). In the area of food safety, educated and employed consumers are more concerned about such safety and are willing to pay a premium for it (see, e.g., Latouche, Rainelli, and Vermersch 1998). In the event of an outbreak, consumers who are younger are more susceptible to negative media (Verbeke, Ward, and Viaene 2000). Common trends observed during outbreaks, for example in the case of BSE, are substitution to other meats and more emphasis on food safety (McCluskey et al. 2005). Firms that handle organic and food products with quality assurance systems are found to benefit in these situations. With an outbreak, consumers are willing to pay more for products that are tested and labeled, i.e. they are more willing to pay for products that provide information in comparison to products that do not.

In general, consumers have not proven to be very open to food treated with some technologies (e.g., irradiation, genetically modified (GM) foods, and antibiotic use in livestock), more so when there is a lack of information regarding the risks attached to them. They may prefer categories of food products that use these technologies if they are offered extra benefits in the form of price discounts, or a health or environmental emphasis (Shogren et al. 1999, Zhang et al. 2004). There is a whole spectrum of degrees of acceptance/rejection of foods created through use of biotechnology (GM foods) as discussed in detail below. Other reasons for acceptance or rejection of technologies can 
be the level of trust associated with government programs, perceptions of science, and the positive or negative influences of the media (Curtis, McCluskey, and Wahl 2004).

Similarly, there is a demand for food products that are explicitly specified as pesticide free. In most cases, it has been found that willingness to pay is expressed by consumers who are more concerned about health and the environment, insensitive to price, younger in age, higher in education, and who have more household income (Magnusson and Cranfield 2005).

Food safety may be assured by practices such as traceability, transparency and assurance (TTA); labeling of different characteristics such as Country of Origin Labeling (COOL); and information on processes such as use of Hazard Analysis Critical Control Points (HACCP). However, there are differences in the European Union and the United States in the objective of implementation of these systems that can ensure food safety. TTA systems in the E.U. have been implemented because it is a requirement to gain access to markets whereas in the U.S. implementation has focused more on consumers' willingness to pay. In other words, these systems are more often mandatory in the E.U. than in the U.S. There are valuation experiments in which consumers have chosen food safety over traceability. Consumers in the U.S. and Canada are found to be more willing to pay for information on animal treatment and food safety assurance than on traceability alone (Dickinson and Bailey 2002).

COOL imparts information on the origin of food products. Various studies show that consumers are willing to pay a higher price for a country of origin label because they use this information as both safety and quality cues. It serves as a means by which consumers can differentiate domestic goods from imports. Hence they are willing to pay 
for the information, especially when they prefer domestic goods and consider them to be safer (Unterschultz, Quagrainie, and Veeman 1998). With COOL, willingness to pay is also dependent on a number of factors such as consumer awareness, price sensitivity, and demographics. Some studies have shown that consumers are concerned about animal welfare, the use of antibiotics in animal feed, and the use of growth hormones in animal production systems (Grannis and Thilmany 2002). This is however subject to the type of study conducted and its objective. To date, the studies of traceability systems put the most emphasis on animal welfare concerns and health effects.

\section{What the Numbers Say}

There have been a number of studies completed that attempt to measure consumer willingness to pay (WTP) for particular food attributes or combinations of attributes. Table 1 presents our review of a sample of these studies published in the last five years organized by country and attribute. Panel A of Table 1 reports findings on consumers' willingness to pay in Canada and the U.S. for three different attributes: traceability, country of origin labeling, and animal welfare. Panel B of Table 1 focuses on WTP estimates for food safety across countries. The Table 1 footnotes provide extensive detail on the design of the studies included in the table.

A common feature in WTP studies is the use of various types of hypothetical (e.g., surveys, choice experiments (conjoint analysis)) and non-hypothetical (e.g., experiments) valuation methodologies. Because we focused on the past five years, the studies included in the table tend to showcase issues that have been prominent during this period, including the impact of BSE and genetic modification, on the attitudes of 
consumers as measured in terms of their WTP for food products with particular attributes. The figures in the table are reported either as percentage changes from a base price, dollars per pound, or dollars per product (e.g., a sandwich). Many studies are for meat products. There is variation in the form of meat used in experiments or surveys; common forms are sandwiches, steak, or hamburger. A majority of the experimental studies have been conducted with students at different universities. In some studies, there is a WTP range as the base price was varied in the design of offered prices in the survey. Estimated premiums are often large in magnitude. This raises the concern that hypothetical valuation methodologies may overstate WTP (i.e., there is hypothetical bias). Consumer characteristics have varying and non-uniform effects in different WTP studies.

Studies of consumers' valuation of the use of genetic modification have been done in a broad range of countries. Studies show that GM/non-GM foods have different interpretations in these countries. Some countries are more open to GM food, while others are not. Countries where GM food is disfavored outnumber those where it is more favored. This research is discussed in more detail in the case study below.

Estimates are also available in the Willingness to Accept (WTA) format where consumers state their willingness to accept a food product depending on the incentive offered. The designs of WTP and WTA experiments are similar except that items to be exchanged are reversed. Nayga, Woodward, and Aiew (2005) illustrate the difference in formats. In a WTP experiment, after information about the nature of food irradiation is provided, each respondent is given a pound of non-irradiated ground beef and some money as a gift for participating in the study. The respondent is then asked his/her willingness to exchange the pound of non-irradiated ground beef and a first bid money 
offer for a pound of irradiated ground beef. In contrast, each WTA respondent is given a pound of irradiated ground beef as a gift for participating in the study. The respondent is then asked his/her willingness to exchange the pound of irradiated ground beef for a pound of non-irradiated ground beef and some money. Recent literature shows wide disparities in the estimates of WTP and WTA for a food product with different attributes. Uncertainty associated with characteristics or quality of the good is likely to contribute to the observed discrepancies between WTP and WTA (Isik 2004). We have not included WTA estimates in Table 1 because the WTP format has been used in a much broader set of studies, which facilitates our objective to compare studies.

In addition to eliciting estimates of consumers' WTP for food products, a number of studies focus on other important aspects of demand such as the inherent reasons for, and factors that affect, their choices. These factors include demographics such as education, income, and age as discussed above. Different studies can report very different WTP figures for the same characteristic of a food product. For example, in the case of non-GM vegetable oil in the U.S., the premium estimate ranges from $5-62 \%$ across studies. The variation may be attributable to hypothetical bias, consumer characteristics, or study design. Across countries, even more variables, such as differences in the income elasticity of demand at different average income levels, may affect the range of WTP estimates. Which aspects of consumer demand are being measured may be unclear across studies. For example, studies on the labeling of the country of origin do not consistently distinguish between consumer demand for information on domestic, as opposed to imported foods. The number of other product attributes included in the study design may also influence the WTP elicited for a country of origin label (Ehmke 2006). Table 1 is 
dominated by work on GM/non-GM food. However, in the U.S. and Canada there are a number of studies spread over consumers' WTP for food safety, animal welfare, COOL, and traceability.

\section{Summary}

Recent literature suggests that consumers are willing to pay varying amounts for enhancement of some food attributes or the absence of other attributes, and, importantly for information that they believe provides quality assurance. At the least, we can say that these WTP differentials depend on the product, the attribute, and the country. The reported, although perhaps not the actual, amounts may also depend on the study design. One potentially important factor that is not standardized across studies is the information environment in which valuations are elicited. In most studies, the consumer is presented information on the product attributes being valued before or during the valuation process. This immediate information environment may affect the valuations elicited from study to study. While the size of the premiums (or discounts) consumers would be willing to pay (or to accept) for products with particular attributes vary across countries and consumer segments, the key implications of valuation studies for trends in international agricultural and food trade may be in whether consumers apply a premium or discount and the reasons for them doing so. The blank cells in Table 1 suggest there is a potential for more research on some attributes. This research could be helpful to marketing agencies and public policy makers as well as in understanding consumer demand. The meta- and comparative analyses that have been completed recently suggest paths to structuring research so that it yields more than snapshot pictures of the strength of consumer demand for particular attributes or attribute combinations. 


\section{Consumer Demand in a Global Trade Environment: The Case of Genetically Modified Foods}

Globalization is having a significant impact on consumer demand for food quality. The global sourcing of food products means the year-around availability of both commonplace and exotic products. In addition, the variety within product categories is greatly extended with global trade. Global food sourcing may add to the attributes of concern to consumers in making food choices. For example, if consumers are buying salmon, they may want to know where and how the salmon was produced in order to gauge possible undesirable contaminants and desirable fatty acid levels, as well as to know what environmental effects are associated with the product. On the supply chain side, retailers have to coordinate and control the attributes of their offerings across longer supply chains.

One of the most controversial consumer demand subjects globally is the acceptance/rejection of genetically modified (GM) food. International trade has been significantly affected by differences in the reception of biotechnology across countries. An extensive chicken and egg argument is ongoing about whether differences in government policy toward GM foods across countries are the result of different consumers' (citizens') views toward biotechnology or whether government policy has led consumer acceptance/rejection. The long-running WTO dispute brought by the United States against the European Union based on the E.U. policy toward GM foods is centered on arguments over the use and adequacy of risk assessments. However, this trade conflict also reflects different perceptions of what the market for GM foods would have looked 
like in the E.U. if not for European policy that has been inhospitable to the introduction of GM foods. Essentially the underlying U.S. view is that these products would have been accepted in the E.U. if the governments had not put up barriers to them. Similarly, media coverage may affect consumer acceptance (see, e.g., Kalaitzandonakes, Marks, and Vickner 2004). We cannot resolve the chicken and egg arguments of which came firstconsumer response, government policy, or media coverage. However, there is a large number of studies that documents the disparity across countries in demand responses to GM products and the underlying reasons for the disparity (Chern et al. 2002; Springer et al. 2002; Kim and Kim 2004; Curtis, McCluskey, and Wahl 2004; Li et al. 2003).

The proponents of biotechnology typically emphasize its ability to deliver an improved supply of food and medicine, and an increase in environmental quality due to less need for pesticides. Opponents argue biotechnology is an interference with nature that has unknown and potentially disastrous effects on health and the environment (Nelson 2001). Zhang et al. (2004) observe that American consumers do not seem to exhibit concerns over GM foods. However, consumers remain concerned about the potential risks of GM crops on human health (Ganiere and Chern 2004). Perceived benefits may outweigh perceived risks if the GM products offer extra benefits over traditional products (such as a price discount, or health or environmental attributes). In a study comparing U.S. and Chinese consumers, Zhang et al. (2004) found that the attitudes of the majority of American and Chinese consumers are generally supportive of the new technology. However, consumers in both countries are clearly more willing to accept GM plant products than GM animal products. 
Uncertainties associated with consumer acceptance of GM foods have emerged in many countries, especially in Europe and Japan (Chern et al. 2002). Springer et al. (2002) found important differences in acceptance of GM foods within Europe. The mean rejection rate for the 15 countries studied was $73 \%$ but it ranged from $85 \%$ in Greece to 58\% in Great Britain. In another study, Carlsson, Frykblom, and Lagerkvist (2004) found that Swedish consumers did not see GM food as equivalent to conventional food. Consequently, the Swedish consumers support mandatory labeling and are willing to pay higher prices to ensure a total ban on the use of GM in animal fodder.

Curtis, McCluskey, and Wahl (2004) find that more positive consumer perceptions toward GM may stem from more urgent food needs. In Asia, Japan and Korea stand out as countries with low consumer acceptance for GM food in comparison with other countries such as China and Taiwan that show greater acceptance. A study of acceptance of GM food in Beijing shows that consumers were willing to pay a $38 \%$ premium for GM rice and a $16.3 \%$ premium for GM soybeans over their conventional counterparts ( $\mathrm{Li}$ et al. 2003). In Korea, Kim and Kim (2004) found a large number of consumers who are willing to buy GM products, if they are offered at a discount. Li et al. (2003) report that consumers in China have positive attitudes toward the use of biotechnology in agriculture, although they have little knowledge. Their attitudes are influenced by positive media coverage that is controlled by the government. Younger people are more willing to purchase GM food products with product-enhancing attributes, which indicates that the Chinese market may be more open to GM foods in the future. Additionally, government investment in biotechnology remains strong, as China works to fulfill its food self-sufficiency policies. 
De Groote et al. (2004) argue that although consumers in Africa may be critical towards food with GM content, they may not be able to reject this food given concerns about food shortages, nutritional intake, and a mismatch of per capita food production with population growth. Kimenju and De Groote (2005) find that consumers in Kenya have positive perceptions of the production enhancing characteristics of GM crops. However negative perceptions regarding environmental risk, health risk and ethical and equity concerns, which are not based on scientific evidence, dominate the consumers' attitude towards GM food. Willingness to pay is affected negatively by health risk perceptions and ethical and equity concerns, while trust in government to ensure food quality has a positive influence in this study.

GM technology has generally been accepted in North and South America, while the European Union, Japan, and South Korea remain very reluctant. China and Taiwan also have higher levels of acceptance. A generalization that can be made across studies is that better educated and higher income groups are more aware of GM crops. This awareness holds with respect to the potential benefits of the technology as well as regarding the potential negative effects, including those on the environment and on biodiversity.

Two separate analyses provide further systematic insights into how consumers value GM foods. Lusk et al. (2005) conducted a meta-analysis of 25 studies that together report 57 valuations of GM food. Due to wide differences regarding the use of demographic variables in these studies, this meta-analysis did not attempt to capture the effect of demographic differences on consumer valuation. In addition, it was only able to focus on point estimates of willingness to pay (or to accept) because many of the 
underlying studies did not present confidence intervals on their estimates. The authors find that a high percentage of the variation in premiums found for non-GM food over GM food between studies are explained by geographical region (European consumers have the highest premium), who is asked for a valuation (the premiums of shoppers are lower than those of the general population), how the study is conducted (in-person valuations are higher than those by mail or phone), whether the study is hypothetical or nonhypothetical (non-hypothetical designs yield lower valuations), whether the study estimates willingness to pay or willingness to accept (WTA valuations are higher than those for WTP), and product type (GM meat is the least desired GM food). Overall, premiums for non-GM food averaged from $42 \%$ (unweighted average of all data) to $23 \%$ (weighted average excluding one outlier). Lusk et al. (2005) state that, "This analysis leads us to conclude that previous research has effectively identified what consumers' valuations are, given a particular valuation method (p. 41)." They go on to note that because valuations are significantly affected by elicitation method, users of these studies must be careful in choosing which types of studies to rely on in their decision making.

In a second analysis, McCluskey, Grimsrud, and Wahl (2007) compare the roles of country (Canada, China, Japan, Norway, and the United States), demographic, and knowledge differences in explaining consumer valuation of GM foods using in-person surveys in supermarket and shopping areas, a contingent valuation methodology, and different products depending on the country. They find that consumers required on average a discount of $60 \%$ for the GM food studied in Japan, of 50\% in Norway, of $24 \%$ in Canada, and of $24 \%$ or $8 \%$, depending on the product and survey location, in the U.S. In China, a premium of $38 \%$ was elicited. Knowledge about GM products and 
demographic variables (formal education, gender, age, and whether there were children under 18 in the household) did not have uniform effects on consumer valuation across the countries studied. Some variables were statistically positive or negative depending on the country. McCluskey, Grimsrud, and Wahl (2007) conclude that "the stage of economic development, along with cultural attitudes valuing tradition and skepticism of science, must all be considered (p. 13)" when evaluating consumer preferences for GM food.

Overall, research shows clear patterns of differences in consumer demand for GM foods across countries. These differences may influence government policy or vice versa; nonetheless they clearly exist. Together differences in consumer demand and policies affect the exchange of goods and trade relations. To date consumer knowledge and demographic factors do not appear to provide clear predictions of consumer valuation across countries, while study design likely has a more uniform effect on the valuations elicited. The result from a trade perspective is a picture of a series of differentiated markets. In this regard, GM foods are probably the most salient example of the effect of consumer demand on agricultural and food trade.

\section{Is Consumer Demand a Driving Force in Global Agricultural and Food Trade?}

Managing food safety risks and providing desired levels of other quality attributes is a complex task, particularly in globalized agricultural and food markets. Farmers, food processors, food distributors, retailers, and food service companies are faced with varied demands for food quality, including food safety, from consumers.

We have reviewed recent studies, meta-analyses, and comparative studies of consumer willingness to pay for particular food attributes and packages of attributes. The 
studies generally detect a willingness to pay but the magnitude varies by attribute, food product, country, and study design. This literature, along with trend analysis of market developments, clearly suggests that consumer demand is a major determinant of agricultural and food trade. This effect is evident in the ongoing differentiation of food products on the basis of a growing range of attributes.

In looking to the future, however, we conclude that the body of research completed on consumer valuation of foods with different attributes indicates that in terms of its life cycle, the impact of changing consumer demand for quality on agricultural and food trade has passed through its introduction and growth stages. These market forces are now in their maturity in many markets. In those where they are not fully in place, the outlines of where they are going are clearly visible. We expect consumer demand for quality to remain a strong force in global trade over the coming decades. However, the shape of that impact is known and, in large part, the adjustment to it has already occurred or is ongoing. Consumer demand factors will evolve in the direction of adding to and further differentiating the list of attributes. This leaves room for enterprising companies and countries to respond to and lead consumer demand. 


\section{References}

Alfnes, F., and K. Rickertsen. 2003. "SC-X: Calibrating Stated Choice Surveys with Experimental Auction Markets." Paper presented at the American Agricultural Economics Association Annual Meeting, Montreal, Canada, 27-30 July.

Angulo, A.M., and J.M. Gill. 2004. “Consequences of BSE on Consumers' Attitudes, Perceptions and Willingness to Pay for Certified Beef in Spain.” Paper presented at the 84th EAAE Seminar 'Food Safety in a Dynamic World,' Zeist, The Netherlands, 8-11 February.

Carlsson, F., P. Frykblom, and C.J. Lagerkvist. 2004. "Consumer Benefits of Labels and Bans on Genetically Modified Food-An Empirical Analysis Using Choice Experiments." Paper presented at the American Agricultural Economics Association Annual Meeting, Denver CO, 1-4 August.

Chen, H., and W.S. Chern. 2002. "Consumer Acceptance of Genetically Modified Foods." Paper presented at the Annual Meeting of the American Agricultural Economics Association, Long Beach CA, 28-31 July.

Chern, W.S., K. Rickertsen, N. Tsuboi, and T.-T. Fu. 2002. "Consumer Acceptance and Willingness to Pay for Genetically Modified Vegetable Oil and Salmon: A MultipleCountry Assessment.”AgBioForum 5(3):105-112.

Chiang, F.-S. 2004. "An Analysis of Consumer Perception and Acceptance of Genetically Modified Foods in Taiwan." Paper presented at the 8th ICABR International Biotechnology Conference, Ravello, Italy, 8-11 July.

Curtis, K.R., J.J. McCluskey, and T.I. Wahl. 2004. “Consumer Acceptance of Genetically Modified Food Products in the Developing World." AgiBioForum 7(1/2):70-75. 
De Groote H., S. Mugo, D. Bergvinson, G. Owuor, and B. Odhiambo. 2004. "Debunking the Myths of GM Crops for Africa: The Case of BT Maize in Kenya." Paper presented at the American Agricultural Economics Association Annual Meeting, Denver CO, 1-4 August.

Dickinson, D.L., and D. Bailey. 2002. "Meat Traceability: Are U.S. Consumers Willing to Pay for It?” Journal of Agricultural and Resource Economics 27(2): 348-364.

Dickinson, D.L., J.E. Hobbs, and D. Bailey. 2003. “A Comparison of U.S. and Canadian Consumers' Willingness to Pay for Red-Meat Traceability.” Paper presented at the American Agricultural Economics Association Annual Meetings, Montreal, Canada, 27-30 July.

Dimitri, C., and L. Oberholtzer. 2005. "Market-Led Versus Government-Facilitated Growth: Development of the U.S. and E.U. Organic Agricultural Sectors." Washington, DC: U.S. Department of Agriculture, Economic Research Service WRS05-05, August.

Ehmke, M.T. 2006. "International Differences in Consumer Preferences for Food Country-of-Origin: A Meta-Analysis.” Paper presented at the American Agricultural Economics Association Meeting, Long Beach CA, 23-26 July.

Florax, R.J.G.M., C.M. Travisi, and P. Nijkamp. 2005. "A Meta-Analysis of the Willingness to Pay for Reductions in Pesticide Risk Exposure." European Review of Agricultural Economics 32(4):441-467.

Ganiere, P., and W.S. Chern. 2004. "Consumer Acceptance of Genetically Modified Foods: A Profile of American Consumers." Paper presented at the American Agricultural Economics Association Annual Meeting, Denver CO, 1-4 August. 
Grannis, J., and D.D. Thilmany. 2002. "Marketing Natural Pork: An Empirical Analysis of Consumers in the Mountain Region.” Agribusiness 18(4):475-489.

Hobbs, J.E., D. Bailey, D.L. Dickinson, and M. Haghiri. 2005. "Traceability in the Canadian Red Meat Sector: Do Consumers Care?" Canadian Journal of Agricultural Economics 53:47-65.

Isik, M. 2004. "Does Uncertainty Affect the Divergence between WTP and WTA Measures?” Economics Bulletin 4(1):1-7.

Kalaitzandonakes, N., L.A. Marks, and S.S. Vickner. 2004. "Media Coverage of Biotech Foods and Influence on Consumer Choice." American Journal of Agricultural Economics 86(5):1238-1246.

Kaneko, N., and W.S. Chern. 2003. "Consumer Acceptance of Genetically Modified Foods: A Telephone Survey." Paper presented at the American Agricultural Economics Association Annual Meeting, Montreal, Canada, 27-30 July.

Kaneko, N., and W.S. Chern. 2004. "Willingness to Pay for Non-Genetically Modified Food: Evidence of Hypothetical Bias from an Auction Experiment in Japan.” Paper presented at the American Agricultural Economics Association Annual Meeting, Denver CO, 1-4 August.

Kim, H.S., and K. Kim. 2004. "A Multi-Country Assessment of Consumer Attitudes of Genetically Modified Foods and the Implications for New Labeling System.” Paper presented at the American Agricultural Economics Association Annual Meeting, Denver CO, 1-4 August.

Kimenju, S.C., and H. De Groote. 2005. 'Consumers' Willingness to Pay for Genetically Modified Foods in Kenya." Paper presented at the $11^{\text {th }}$ International Congress of the 
EAAE (European Association of Agricultural Economists), The Future of Rural Europe in the Global Agri-Food System, Copenhagen, Denmark, August.

Latouche, K., P. Rainelli, and D. Vermersch. 1998. "Food Safety Issues and the BSE Scare: Some Lessons from the French Case.” Food Policy 23:347-356.

Li, Q., K.R. Curtis, J.J. McCluskey, and T.I. Wahl. 2003. "Consumer Attitudes toward Genetically Modified Foods in Beijing, China." AgBioForum 5(4):145-152.

Lin, W., A. Somwaru, F. Tuan, J. Huang, and J. Bai. 2005. "Consumer Attitudes toward Biotech Foods in China." Paper presented at the American Agricultural Economics Association Annual Meeting, Providence RI, 24-27 July.

Lusk, J.L., J. Roosen, and J.A. Fox. 2001. "Demand for Beef from Cattle Administered Growth Hormones or Fed Genetically Modified Corn: A Comparison of Consumers in France, Germany, the United Kingdom, and the United States." Paper presented at the American Agricultural Economics Association Annual Meeting, Chicago IL, August.

Lusk, J.L., J. Roosen, and J.A. Fox. 2003. "Demand for Beef from Cattle Administered Growth Hormones or Fed Genetically Modified Corn: A Comparison of Consumers in France, Germany, the United Kingdom, and the United States." American Journal of Agricultural Economics 85(February):16-29.

Lusk, J.L., M. Jamal, L. Kurlander, M. Roucan, and L. Taulman. 2005. “A Meta-Analysis of Genetically Modified Food Valuation Studies." Journal of Agricultural and Resource Economics 30(1):28-44.

Mabiso, A., J. Sterns, L. House, and A. Wysocki. "Estimating Consumers' Willingness to Pay for Country of Origin Labels in Fresh Apples and Tomatoes: A Double-Hurdle 
Probit Analysis of American Data Using Factor Scores." Paper presented at the American Agricultural Economics Association Annual Meeting, Providence RI, 2427 July.

Magnusson, E., and J.A.L. Cranfield. 2005. “Consumer Demand for Pesticide Free Food Products in Canada: A Probit Analysis." Canadian Journal of Agricultural Economics 53:67-81.

McCluskey, J.J., K.M. Grimsrud, H. Ouchi, and T.I. Wahl. 2005. "Bovine Spongiform Encephalopathy in Japan: Consumers' Food Safety Perceptions and Willingness to Pay for Tested Beef." The Australian Journal of Agricultural and Resource Economics 49:197-209.

McCluskey, J.J., K.M. Grimsrud, and T.I. Wahl. 2007. "Comparison of Consumer Responses to Genetically Modified Foods in Asia, North America, and Europe.” In R.E. Just, J. Alston, and D. Zilberman, eds. Regulating Agricultural Biotechnology: Economics and Policy. New York, NY: Springer/Kluwer Academic Publishers, pp. 114.

Nayga, Jr., R.M., R. Woodward, and W. Aiew. 2005. "Experiments on the Divergence between Willingness to Pay and Willingness to Accept: The Issue Revisited." Economics Bulletin 17(4):1-5.

Nayga Jr., R.M., W. Aiew, and R. Woodward. 2004. "Willingness to Pay for Irradiated Food: A Non Hypothetical Market Experiment." Paper presented at the 84th EAAE Seminar 'Food Safety in a Dynamic World,' Zeist, The Netherlands, 8-11 February. Nelson, C.H. 2001. "Risk Perception, Behavior, and Consumer Response to Genetically Modified Organisms.” American Behavioral Scientist 44:1371-1388. 
Peterson, H.H., and Y. Chen. 2005. "The Impact of BSE on Japanese Retail Meat Demand.” Agribusiness 21(3):313-327.

Reardon, T., P. Timmer, and J. Berdegue. 2004. "The Rapid Rise of Supermarkets in Developing Countries: Induced Organizational, Institutional, and Technological Change in Agrifood Systems.” Electronic Journal of Agricultural and Development Economics 1(2):168-183.

Shogren, J.F., A.F. John, D.J. Hayes, and J. Roosen. 1999. “Observed Choices for Food Safety on Retail, Survey, and Auction Markets.” American Journal of Agricultural Economics 18(5):1192-1199.

Springer, A., K. Mattas, G.T. Papastefanou, and A. Tsioumanis. 2002. "Comparing Consumer Attitudes towards Genetically Modified Food in Europe.” Mimeo.

Tonsor, G.T., and T.C. Schroeder. 2003. "European Consumer Preferences for U.S. and Domestic Beef: Willingness to Pay for Source Verification, Hormone-Free, and Genetically Modified Organism-Free Beef." Paper presented at the American Agricultural Economics Association Annual Meeting, Montreal, Canada, 27-30 July.

Umberger, W.J., D.M. Feuz, C.R. Calkins, and B.M. Sitz. 2003. “Country of Origin Labeling of Beef Products: U.S. Consumers' Perceptions." Journal of Food Distribution Research 34(3):103-116.

Unterschultz, J., K. Quagrainie, and M. Veeman. 1998. "Effects of Product Origin and Selected Demographics on Consumer Choice of Red Meats." Canadian Journal of Agricultural Economics 46:201-219. 
Verbeke, W., R.W. Ward, and J. Viaene. 2000. "Probit Analysis of Fresh Meat Consumption in Belgium: Exploring BSE and Television Communication Impact.” Agribusiness 16:215-234.

Zhang, C., J. Bai, J. Huang, W.K. Hallman, C. Pray, and H.L. Aquino. 2004. "Consumer Acceptance of Genetically Modified Foods: A Comparison between the U.S. and China." Paper presented at the American Agricultural Economics Association Annual Meeting, Denver CO, 1-4 August. 
Table 1. Recent Consumer Willingness to Pay Studies by Country and Product Attributes

\begin{tabular}{|c|c|c|c|c|c|c|}
\hline & \multicolumn{2}{|c|}{ Animal welfare } & \multicolumn{2}{|c|}{$\begin{array}{c}\text { Country of Origin } \\
\text { Labeling }\end{array}$} & \multicolumn{2}{|c|}{ Traceability } \\
\hline & Beef & Pork & Beef & Produce & Beef & Pork \\
\hline Canada & $\begin{array}{l}18 \%^{\mathrm{a}} \text { and } \\
19 \%^{\mathrm{b}} \\
\text { sandwich }\end{array}$ & $\begin{array}{l}16 \%^{\mathrm{a}} \text { and } \\
13 \%^{\mathrm{b}} \\
\text { sandwich }\end{array}$ & & & $\begin{array}{l}\mathbf{7 \%} \%^{\mathrm{a}} \text { and } \\
\mathbf{9 \%}{ }^{\mathrm{b}} \\
\text { sandwich }\end{array}$ & $\begin{array}{l}10 \%^{\mathrm{a}} \text { and } \\
7 \%^{\mathrm{b}} \\
\text { sandwich }\end{array}$ \\
\hline \multirow[t]{3}{*}{ U.S. } & $\begin{array}{l}16 \%^{\mathbf{b}} \text { and } \\
\$ 0.50^{c} \text { per } \\
\text { sandwich }\end{array}$ & $\begin{array}{l}\mathbf{2 0 \%} \mathbf{6}^{\mathrm{b}} \\
\text { and } \\
\$ 0.53^{\mathrm{c}} \text { per } \\
\text { sandwich }\end{array}$ & $\begin{array}{l}11 \%^{\mathrm{h}} \\
\text { steak, } \\
24 \%{ }^{\mathrm{h}} \\
\text { hamburger }\end{array}$ & $\begin{array}{l}\mathbf{\$ 0 . 4 9 / \mathbf { l b } ^ { \mathbf { m } }} \\
\text { apples, } \\
\mathbf{\$ 0 . 4 8 / \mathbf { l b } ^ { \mathbf { m } }} \\
\text { tomatoes }\end{array}$ & $\begin{array}{l}\mathbf{7 \%} \%^{\mathbf{b}} \text { and } \\
\$ \mathbf{0 . 2 3 ^ { \mathbf { c } }} \text { per } \\
\text { sandwich }\end{array}$ & $\begin{array}{l}\mathbf{1 8 \%} \%^{\mathbf{b}} \text { and } \\
\mathbf{\$ 0 . 5 0 ^ { c }} \text { per } \\
\text { sandwich }\end{array}$ \\
\hline & \multicolumn{6}{|c|}{ Food safety } \\
\hline & & & Pork & & \multirow{2}{*}{\multicolumn{2}{|c|}{ Grain/ Salmon }} \\
\hline Canada & \multicolumn{2}{|c|}{$20 \%^{\mathrm{a}}$ and $18 \%^{\mathrm{b}}$ sandwich } & \multicolumn{2}{|c|}{$\begin{array}{l}17 \%^{\mathrm{a}} \text { and } 13 \%^{\mathrm{b}} \\
\text { sandwich }\end{array}$} & & \\
\hline U.S. & \multicolumn{2}{|c|}{ 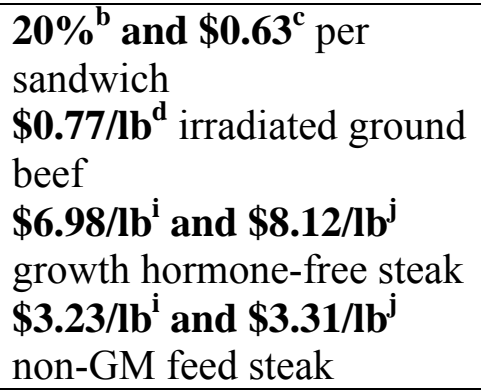 } & \multicolumn{2}{|c|}{$\begin{array}{l}23 \%^{\mathbf{b}} \text { and } \mathbf{\$ 0 . 5 9} \mathbf{c}^{\mathrm{c}} \text { per } \\
\text { sandwich }\end{array}$} & \multicolumn{2}{|c|}{ 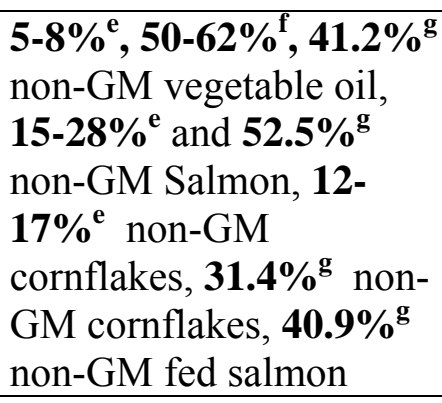 } \\
\hline France & \multicolumn{2}{|c|}{ 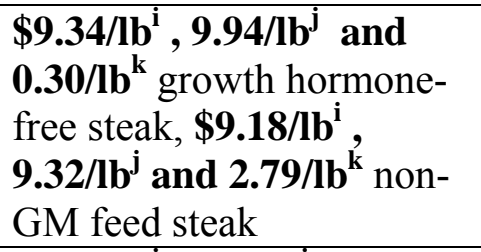 } & & & & \\
\hline Germany & \multicolumn{2}{|c|}{$\begin{array}{l}\$ 6.99 / \mathbf{l}^{\mathrm{i}}, 7.29 / \mathbf{l} \mathbf{b}^{\mathrm{j}} \text { and } \\
1.93 / \mathbf{b}^{\mathbf{k}} \text { growth hormone- } \\
\text { free steak, } \$ 7.63 / \mathbf{l b}^{\mathbf{i}} \text {, } \\
7.67 / \mathbf{b}^{\mathbf{j}} \text { and } 2.55 / \mathbf{l} \mathbf{b}^{\mathbf{k}} \text { non- } \\
\text { GM feed steak }\end{array}$} & & & & \\
\hline Norway & \multicolumn{2}{|c|}{$\begin{array}{l}\$ 1.39 / / b^{n} \text { hormone-free } \\
\text { steak }\end{array}$} & & & \multicolumn{2}{|c|}{$\begin{array}{l}\mathbf{5 5 - 6 9 \%}{ }^{\mathrm{f}} \text { non-GM } \\
\text { vegetable oil, } \mathbf{5 4 . 2} \%{ }^{\mathrm{f}} \\
\text { non-GM fed salmon and } \\
\mathbf{6 7 \%}{ }^{\mathrm{f}} \text { non-GM salmon }\end{array}$} \\
\hline Spain & \multicolumn{2}{|c|}{$5 \%^{\circ}$ label certified beef } & & & & \\
\hline U.K. & \multicolumn{2}{|c|}{ 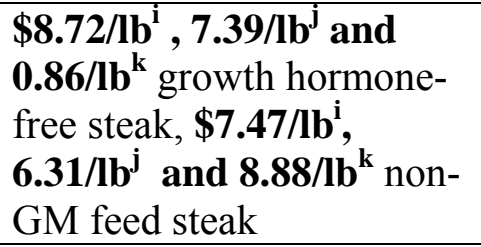 } & & & & \\
\hline
\end{tabular}


Table 1. Recent Consumer Willingness to Pay Studies by Country and Product Attributes (Continued)

\begin{tabular}{|c|c|c|c|}
\hline & \multicolumn{3}{|c|}{ Food safety } \\
\hline & Beef & Pork & Grain/Salmon \\
\hline Japan & $\mathbf{5 6} \%^{\mathrm{p}}$ BSE-tested & & $\begin{array}{l}\mathbf{3 0 - 4 0 \%} \%^{\mathbf{q}} \text { non-GM canola } \\
\text { oil, } \mathbf{3 3 - 4 0} \mathbf{\%}^{\mathbf{f}} \text { non-GM } \\
\text { vegetable oil }\end{array}$ \\
\hline Korea & & & $\begin{array}{l}\mathbf{5 4 . 2} \%^{1} \text { non-GM } \\
\text { vegetable oil, } 81.2 \%{ }^{1} \\
\text { non-GM tofu }\end{array}$ \\
\hline Taiwan & & & $\begin{array}{l}\mathbf{1 7 - 2 1 \%}{ }^{\mathrm{t}} \text { non-GM } \\
\text { vegetable oil, 21.19\% } \\
\text { non-GM soybean oil, } \\
\mathbf{3 7 . 4 2 \%}{ }^{\mathrm{t}} \text { non-GM tofu, } \\
\mathbf{1 0 8 . 4 \%}{ }^{\mathrm{t}} \text { non-GM fed } \\
\text { salmon }\end{array}$ \\
\hline China & & & 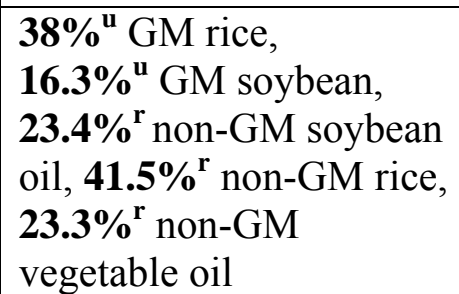 \\
\hline Kenya & & & $13.7 \%^{\mathrm{s}} \mathrm{GM}$ maize \\
\hline
\end{tabular}

${ }^{\text {a} H o b b s, ~ B a i l e y, ~ D i c k i n s o n ~ a n d ~ H a g h i r i ~} 2005$

Methodology: Vickrey second price auction

Time of study: March 2002

Place of study: Saskatchewan and Ontario; Canada

Food product being studied: Ham and roast beef sandwich

bickinson, Hobbs and Bailey 2003

Methodology: Vickery style auction experiments

Time of study: October 2001 and March 2002

Place of study: Logan, Utah; USA and Saskatoon, Saskatchewan; Canada

Food product being studied: Ham and roast beef sandwich

'Dickinson and Bailey 2002

Methodology: Lab auction study, non-hypothetical bid data

Time of study: October 2001

Place of study: Logan, Utah; USA

Food product being studied: Ham and roast beef sandwich

${ }^{\mathrm{d}}$ Nayga, Aiew, Woodward 2004

Methodology: Face to face WTP experiment, Contingent Valuation Method

Time of study: March- June 2002

Place of study: Austin, Houston, San Antonio, and Waco, Texas; USA

Food product being studied: Irradiated ground beef 


\section{${ }^{\mathrm{e}}$ Chen and Chern 2002}

Methodology: Contingent Valuation Method, Mail survey

Time of study: March 2001

Place of study: Columbus, Ohio; USA

Food product being studied: non-GM vegetable oil, non-GM salmon and non-GM cornflake breakfast cereal

Note: GM and GM-fed salmon in same category

fChern, Rickertsen, Tsuboi and Fu 2002

Methodology: Stated preference approach, National telephone survey

Time of study: March-April 2002

Place of study: Agricultural university of Norway, Norway and Ohio State University, USA

Food product being studied: non-GM vegetable oil, non-GM fed salmon and non-GM salmon Note: Mean WTP is measured as a range because the base price for GM food was varied in the design of offered prices in the survey.

${ }^{g}$ Kaneko and Chern 2003

Methodology: Contingent Valuation Method, Telephone survey

Time of study: April 2002

Place of study: sample entire US

Food product being studied: non-GM vegetable oil, non-GM cornflake cereal, non-GM-fed salmon, non-GM salmon

Note: WTP highest to non-GM salmon and different from GM-fed salmon due to weaker aversion to GM foods involving only modification of plant genes

humberger, Feuz, Calkins, and Sitz 2003

Methodology: Face to face survey and auction

Time of study: 2002

Place of study: Chicago and Denver; USA

Food product being studied: Steak and hamburger- beef

Note: "USA guaranteed" label

i'Lusk, Roosen and Fox 2001

Methodology: Contingent Valuation Method, Mail survey

Time of study: Spring 2000

Place of study: France, Germany, UK and USA

Food product being studied: Hormone-free, GM-free feed beef steak

${ }^{j}$ Lusk, Roosen and Fox 2003

Methodology: Contingent Valuation Method, Mail survey

Time of study: Spring 2000

Place of study: France, Germany, UK and USA

Food product being studied: Hormone-free, GM-free feed beef steak

Note: Estimated premiums are large in magnitude as consumers overstate their WTP in hypothetical settings (hypothetical bias). Relative magnitude of the WTP values assuming hypothetical bias is similar across countries.

${ }^{\mathrm{k}}$ Tonsor and Schroeder 2003

Methodology: Survey and choice experiments

Time of study: August 2002

Place of study: London; UK, Frankfurt; Germany and Paris; France

Food product being studied: Hormone-free and GM-free beef steak 
Note: "USA grown" label

'Kim and Kim 2004

Methodology: Contingent Valuation Method, Student survey

Time of study: Nov-Dec 2003

Place of study: Seoul; Korea

Food product being studied: non-GM vegetable oil and non-GM tofu

mabiso, Sterns, House, and Wysocki 2005

Methodology: Vickrey auction, Face to face interview

Time of study: Nov 2003- Jan 2004

Place of study: Gainsville, Florida, Lansing, Michigan and Atlanta, Georgia; USA

Food product being studied: Fresh apples and tomatoes

Note: "USA grown" label

"Alfnes and Rickertsen 2003

Methodology: Stated Choice survey-Contingent Valuation Method, Experiment auction

Time of study: April 2000

Place of study: Norway

Food product being studied: hormone status for beef

Note: Uses non-hypothetical techniques

${ }^{\circ}$ Angulo and Gil 2004

Methodology: Telephone survey

Time of study: Spring 2002

Place of study: South of Spain

Food product being studied: label-certified beef

${ }^{\mathrm{p}}$ McCluskey, Grimsrud, Ouchi, and Wahl 2005

Methodology: Contingent valuation method, Face to face survey

Time of study: Dec 2001

Place of study: Nogano; Japan

Food product being studied: BSE-tested beef

${ }^{\mathrm{q}}$ Kaneko and Chern 2004

Methodology: Vickery second-price auction

Time of study: Dec 2003

Place of study: Tsukuba, Tokyo; Japan

Food product being studied: non-GM canola oil

${ }^{\mathrm{r}}$ Lin, Somwaru, Tuan, Huang, and Bai 2005

Methodology: Contingent Valuation Method, Personal interviews

Time of study: Fall 2002

Place of study: Beijing, Shandoney, Jiangsu, Zhejiang and Shanghai; China

Food product being studied: Non-GM rice, non-GM soybean oil and non-GM vegetable oil

Note: Overstate WTP due to hypothetical bias. Rice is the main food staple that is not consumed in a highly processed form, while soybean oil is a food product consumed after crushing which destroys much of the DNA sequence; more WTP for non-GM rice.

${ }^{5}$ Kimenju and De Groote 2005

Methodology: Contingent Valuation Method, Face to face interview

Time of study: Nov-Dec 2003

Place of study: Nairobi; Kenya

Food product being studied: GM maize 
${ }^{t}$ Chiang (2004) as cited by Lin, Somwaru, Tuan, Huang, and Bai 2005

Methodology: Contingent Valuation Method, National Telephone survey

Time of study: January 2000-September 2002

Place of study: Taiwan

Food product being studied: non-GM soybean oil, non-GM tofu and non-GM salmon

${ }^{u} \mathrm{Li}$ (2003) as cited by Lin, Somwaru, Tuan, Huang, and Bai 2005

Methodology: Contingent Valuation Method

Time of study: August 2002

Place of study: Beijing, China

Food product being studied: GM rice and GM soybean oil 